\title{
仃舎清掃における労務工数の実態に関する調査研究 A STUDY ON THE ACTUAL CONDITION OF LABOR-MAN HOURS FOR CLEANING WORK IN GOVERNMENT BUILDINGS
}

\author{
杉田 洋*, 佐藤隆良**, 村川三郎***, 近藤貴 道**** \\ Hiroshi SUGITA, Takayoshi SATO, Saburo MURAKAWA \\ and Takamichi KONDO
}

\begin{abstract}
In this paper, the building maintenance costs for the local government office buildings are analyzed and the cleaning costs especially is clarified. Annual cleaning cost is the same amount of about $40 \sim 60 \%$ of annual energy costs. Next, the actual situation of cleaning management is defined based on the analysis of labor-man hour date of the past cleaning works. With regard to the overall ordered floor area to the cleaning contractors in a year, the ordered floor area for the regular cleaning work is a little. With the labor-man hours for the cleaning works, the regular cleaning works of one on two times in a year exceed the daily cleaning works for some government buildings. With the rooms such as, "Passage and Elevator hall", "Rest room", and "Entry hall", labor-man hours spent for the cleaning works occupies more than half of those of the overall number of daily cleaning work. With the rooms and articles such as, "Office room" and "Lighting equipment", labor-man hours spent for the cleaning works occupies more than half of those of the overall number of regular cleaning works. Consequently, in order to reduce cleaning costs, it may be required to focus on the management of these labor-man hours.
\end{abstract}

Keywords : $\quad$ Cleaning, Maintenance Costs, Labor-man hours, Government building 清掃, 管理費, 労務工数, 庁舎

\section{1. 序}

近年、わが国の歳出については、より一層の合理化・効率化・重 点化が必要であり、 5,200 万 $\mathrm{m}^{2}$ ともいわれる官庁建物の保全に対す る予算はますます厳しい状況になると考えられる。これら官庁建物

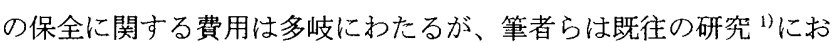
いて、委託管理費を「保守・点検費」と「保安・清掃費」に分類し たうえで、それぞれについて分析を進め、清掃に関する委託管理費 が「保安・清掃費」の過半を占めることを明らかにしている。

またこれまでにも、建物維持管理における清掃業務に関する研究 は行われており、それらは清掃作業従事者の作業環境に関する研究、 室内環境の污染や評価に関する研究に分類される。

前者の研究として、関内ら ${ }^{2)}$ は、病院での院内感染を防ぐために、 空間を「微生物コントロール区域」一般区域」「污染区域」に区分 したうえで、各区域間における清掃用具の往来を避けるために、清 掃用具に区域別のカラ゙ーリングを施すといった用具の管理手法を提 案している。また、水野 ${ }^{3)}$ も、病院での院内感染防止を主題として、 清掃作業従事者それぞれに対して自己管理表を作成し、毎日朝礼・ 終礼の際に各自の健康状態をチェック寸るといった試みを提案して いる。
後者の研究として、上原ら ${ }^{4}$ は、ダ二污染の実態把握、およびそ の繁殖要因の解析を行っており、大塚ら ${ }^{5}$ は、喫煙によって発生す る様々な污染物質の質量変化などを実験により時系列的に把握し、 喫煙が室内空気污染におよぼす影響を明らかにしている。また、清 水ら ${ }^{6)}$ 、吉田ら ${ }^{7)}$ は、空調ダクト内の污れに着目し、吹出しロから の粉䋥飛散や、ダクト内の清掃前後における付着粉塵、および浮遊 微生物の実測結果に基づき清掃の効果について分析を行っている。

また筆者らは、既往の研究 ${ }^{8)}{ }^{99}$ において、利用者評価による清掃 品質管理手法の提案と適用から、清掃発注仕様と在室者による清掃 品質の現状評価の関連について分析を進め、各作業対象における作 業項目および周期が清掃品質の評価におよぼす影響を明らかにして いる。

しかしながら、近年に増して官庁建物の保全に対する予算はます ます嵈しい状況になっている現在、清掃管理費を積算するうえで必 要となる労務工数の実態を明らかにした研究はみられない。

そこで本研究では、地方政令市に建つ複数の庁舎より収集した管 理費の分析から、その全体像を示したうえで、委託管理費を焦点に さらなる分析を進め、管理費における清掃管理費の位置付けを明ら かにする。つぎに、清掃管理費により実際にどのような清掃管理が
* 広島工業大学環境学部 准教授・博士 (工学)

** サトウ・ファシリティーズ・コンサルタンツ 博士 (工学)

$* * *$ 広島大学大学院工学研究科教授. 工博

**** 広島工業大学大学院環境学研究科 大学院生
Assoc. Prof., Faculty of Environmental Studies, Hiroshima Institute of Technology, Dr. Eng. Sato Facilities Consultants, Inc., Dr. Eng.

Prof., Graduate School of Engineering, Hiroshima Univ., Dr. Eng.

Graduate Student, Graduate School of Environmental Studies, Hiroshima Institute of Technology 
なされているのかについて、調査対象である 15 建物の清掃発注仕様 書に基づき、各清掃区分における労務工数をそれぞれ算出し、その 実態を明らかにすることを目的とする。

\section{2. 管理費の分類}

本研究で定義する管理費の構成を図 1 に示す。なお、この分類は 文献 ${ }^{10)}$ を参考にまとめたものである。

管理費は、「一般管理費」「光熱水費」に大別され、それぞれが支 出用途ごとに分類される。「一般管理費」は「委託管理費」「用途品 費」「雑費」に分類されるが、最近の庁舎においては、建物管理の大 部分を外部業者に委託するのが通常であることから、ほぼ「委託管 理費」により構成されるケースが多い。この「委託管理費」は、設 備器機等の保全などに要される「保守・点検費」と、建物の清掃や 警備などに要される「保安・清掃費」で構成される。

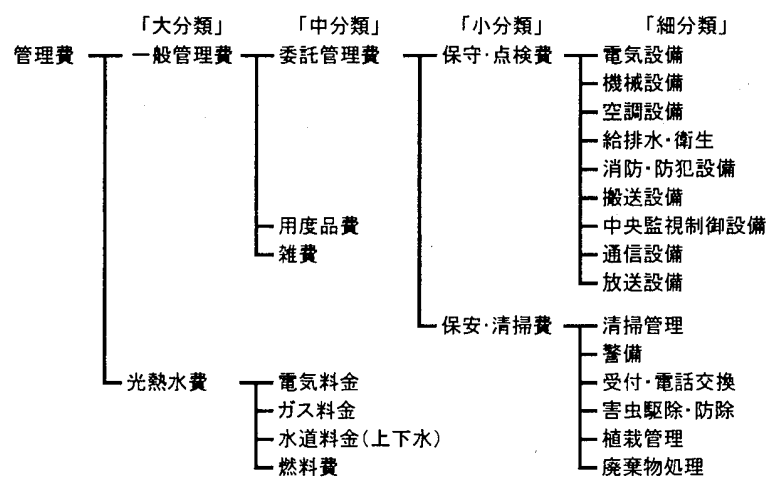

図1 管理費の構成

\section{3. 調査概要}

\section{1 調査対象建物の概要}

対象建物の概要を表 1 に示す。対象建物は、地方政令市に建つ、 建物(1) (15)の 15 物件である。各建物の築後経過年数は、5〜 50 年の 間に分布している。また、延床面積は、988.52〜19,208.87 m²の間 に分布しているが、在室者 1 人あたりに換算すれば約 $20 \sim 30 \mathrm{~m}^{2} / 人$ である。なお、1日あたりの来庁者数は、建物 No. (1)、(4)ではそれぞ れ約 1,700 人、約 310 人と多いが、その他の建物では 150 人前後で ある。また、各建物における、事務室、会議室および廊下などの代 表的な床仕上げ材は塩化ビニルタイルまたはシートである。

\section{2 清掃発注仕様の概要}

各建物における清掃発注仕様を日常清掃の床については表 2、床 以外については表 3 にそれぞれ示す。なお、表中の(1)〜15は、表 1 に示した建物 No.を指している。

通常の庁舎清掃は、庁舎内の各室それぞれに対して、清掃の発注 仕様が細かく設定されておらず、「玄関ホール」「事務室」「会議室」 といった清掃区分ごとに仕様発注されている。また、各清掃区分で 実施される作業は、その周期の長短により、1日に何回、または週 に何回といった「常清掃」月に何回、または年に何回といった「定 期清掃」に大別される。さらに各作業対象については、弾性床や硬 質床といった「床」、壁や屝ガラス、または什器備品といった「床以 外」の 2 つに区分され発注されている。これら、「日常清掃」「定期 清掃」の区分、および「床」「床以外」といった各作業対象の分類定 義については、15 庁舎ともに文献 ${ }^{11)}$ を基準としていることからほ ぼ共通である。しかしながら、「日常清掃」における作業周期や、「定 期清掃」の発注の有無などは庁舎間により若干の差違が認められる。 表のみかたとして、例えば「エレベーター」における「1.弾性床」

\begin{tabular}{|c|c|c|c|c|c|c|c|}
\hline \multicolumn{2}{|c|}{ 建物No. } & (1) & (2) & (3) & (4) & (5) & (6) \\
\hline \multicolumn{2}{|c|}{ 竣工 } & $\begin{array}{l}\text { (1)1956年2月 } \\
\text { (2)1984年9月 }\end{array}$ & $\begin{array}{l}\text { (1)1969年3月 } \\
\text { (2)1981年1月 }\end{array}$ & $\begin{array}{l}\text { (1)1968年3月 } \\
\text { (2)1996年3月 }\end{array}$ & 1982年2月 & $\begin{array}{l}\text { (1)1979年6月 } \\
\text { (2)1978年3月 } \\
\text { (3)2001年3月 }\end{array}$ & 1965年7月 \\
\hline \multicolumn{2}{|c|}{ 跸数 } & $\begin{array}{c}\text { (1)地上6階，地下1階 } \\
\text { (2)地上20階 }\end{array}$ & $\begin{array}{l}\text { (1)地上4階 } \\
\text { (2)地上4階 }\end{array}$ & $\begin{array}{c}\text { (1)地上4階 } \\
\text { (2) 地上12階, 地下 } 1 \text { 階 }\end{array}$ & 地上5階 & $\begin{array}{l}\text { (1)地上4階 } \\
\text { (2)地上5階 } \\
\text { (3)地上3階 }\end{array}$ & 地上5階 \\
\hline \multicolumn{2}{|c|}{ 延床面皘 $\left(\mathrm{m}^{2}\right)$} & $\begin{array}{l}\text { (1) } 19208.87 \\
\text { (2) } 30630\end{array}$ & $\begin{array}{l}\text { (1) } 1678.7 \\
\text { (2) } 2778.02\end{array}$ & $\begin{array}{l}\text { (1) } 3772.8 \\
\text { (2) } 7905.29\end{array}$ & 5769.60 & $\begin{array}{l}\text { (1) } 2362.60 \\
\text { (2) } 2607.28 \\
\text { (3) } 988.52\end{array}$ & 4969.88 \\
\hline \multicolumn{2}{|c|}{ 構造 } & RC造 & $\mathrm{RC}$ 造 & $\mathrm{RC}$ 造 & RC造 & RC造 & RC造 \\
\hline \multirow{2}{*}{\multicolumn{2}{|c|}{$\begin{array}{c}\text { 職員数(人) } \\
\text { 1日あたりの来庁者数 }(\text { 人) }\end{array}$}} & 900 & 76 & 128 & 274 & 173 & 173 \\
\hline & & 約 1700 & 約150 & 約160 & 約 310 & 約170 & 約 180 \\
\hline \multirow{5}{*}{ 主要な床仕上げ } & 事務室·会菨室 & Pタイル張 & ビニル床タイル張 & ビニル床タイル張 & ビニル床タイル張 & ビニル床タイル張 & Pタイル張 \\
\hline & 廊下 & 長尺シート & ビニル床タイル張 & 長尺シート & ビニル床タイル張 & ビニル床タイル張 & Pタイル張 \\
\hline & 玄関ホール & 御影石張 & ビニル床タイル張 & 人造石張り & 炻器筫タイル張 & セラミックプレート張 & テラソー張 \\
\hline & 玄関ホール(外部) & 御影石張 & 花商岩石張 & 人造石張り & 炻器筫タイル張 & セラミックプレート張 & テラソー張 \\
\hline & 便所 & モザイクタイル張 & モザイクタイル張 & モザイクタイル張 & モザイクタイル張 & モザイクタイル張 & モザイクタイル張 \\
\hline \multicolumn{2}{|c|}{ 建物No. } & (7) & (8) & (9) & (11) & (11) & (12) \\
\hline \multicolumn{2}{|c|}{ 率I } & 1999年1月 & 1982年1月 & 1980年3月 & 1980年3月 & 1980年3月 & 1978年6月 \\
\hline \multicolumn{2}{|c|}{ 階数 } & 地上5階、地下1階 & 地上7階，地下 1 階 & 地上4階，地下1階 & 地上5階，地下1階 & 地上4階，地下1階 & 地上4階，地下 1 階 \\
\hline \multirow{2}{*}{\multicolumn{2}{|c|}{$\begin{array}{c}\text { 延床面糟 }\left(\mathrm{m}^{2}\right) \\
\text { 構造 }\end{array}$}} & $3,513 \mathrm{~m}^{2}$ & 11,652 & 6,131 & 7,100 & 6,333 & 7,203 \\
\hline & & SRC造 & SRC & RC & RC & RC & RC \\
\hline \multirow{5}{*}{ 主要な床仕上げ } & 事務室·会議室 & ビニル床タイル張 & Pタイル張 & ビニル床タイル張 & ビニル床タイル張 & ビニル床タイル張 & ビニル床タイル張 \\
\hline & 廊下 & ビニル林イル張 & Pタイル張 & ビニル本タイル張 & ビニル林タイ張 & ビニル床タイル張 & ビニル林タイル張 \\
\hline & 玄関ホール & 炻器筫タイル張 & ビニル林タイル張 & ビニル本タイル張 & ビニル床タイル張 & ビニル床タイル張 & ビニル床タイル張 \\
\hline & 玄関木一ル（外部） & 姑器筫タイル張 & テラゾー張 & 炻器筫タイル張 & セラミックプレート張 & 炻器筫夕イル張 & 炻器筫タイル張 \\
\hline & 便所 & モザイクタイル張 & モザイクタイル張 & モザイクタイル張 & モザイクタイル張 & モザイクタイル張 & モザイクタイル張 \\
\hline \multicolumn{2}{|c|}{ 建物No. } & (13) & (14) & (15) & & & \\
\hline \multicolumn{2}{|c|}{ 竣I } & 1979年 4 月 & 1982年7月 & 1985年3月 & & & \\
\hline \multicolumn{2}{|c|}{ 階数 } & 地上4階，地下1階 & 地上6階，地下 1 㫮 & 地上6階，地下 1 階 & & & \\
\hline \multirow{2}{*}{\multicolumn{2}{|c|}{  }} & 7,150 & 7.732 & 7.758 & & & \\
\hline & & RC & SRC & SRC & & & \\
\hline \multirow{5}{*}{ 主要な床仕上げ } & 事蓩室·会菨室 & ビニル床タイル張 & ビニル床タイル張 & ビニル床タイル張 & & & \\
\hline & 廊下 & ビニル床タイル張 & ビニル床タイル張 & ビニル床タイル張 & & & \\
\hline & 玄関ホール & ビニル床タイル張 & ビニル床タイル張 & ビニル林タイル張 & & & \\
\hline & 玄関ホール(外部) & テラゾー張 & テラソー張 & 妬器筫タイル張 & & & \\
\hline & 便所 & モサイクタイル張 & モザイクタイル張 & モザイクタイル張 & & & \\
\hline
\end{tabular}


表2 床の清掃の作業項目および周期(日常清掃)



表3 床以外の清掃の作業項目および周期(日常清掃)(その1)

\begin{tabular}{|c|c|c|c|c|c|c|c|c|}
\hline \multicolumn{2}{|c|}{ 清擩区分 } & \multicolumn{2}{|r|}{ 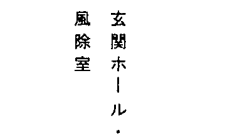 } & $\begin{array}{l}\text { 素 } \\
\text { 格 } \\
\text { 至 }\end{array}$ & \multicolumn{2}{|c|}{$\begin{array}{l}\text { 会 } \\
\text { 湮 } \\
\text { 至 }\end{array}$} & \multicolumn{2}{|c|}{$\begin{array}{ll}E & \text { 郎 } \\
V & T \\
木 & . \\
1 & \\
ル & \end{array}$} \\
\hline \multicolumn{2}{|c|}{ 作業周期 } & $\begin{array}{l}\text { 日 } \\
2 \\
\text { 回 }\end{array}$ & $\begin{array}{l}\text { 昌 } \\
1 \\
\text { 回 }\end{array}$ & $\begin{array}{l}日 \\
1 \\
\text { 回 }\end{array}$ & $\begin{array}{l}\text { 日 } \\
1 \\
\text { 回 }\end{array}$ & $\begin{array}{l}\text { 遇 } \\
3 \\
\text { 回 }\end{array}$ & $\begin{array}{l}日 \\
2 \\
\text { 回 }\end{array}$ & $\begin{array}{l}日 \\
1 \\
\text { 回 }\end{array}$ \\
\hline $\begin{array}{l}\text { 作菜刘象 } \\
\text { ラロママット }\end{array}$ & 作菜項自 & & (2) (1) (15) & & & & & \\
\hline 最加 & 1. 扫き & &  & & & & & \\
\hline 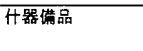 & 1. 除量 & & \begin{tabular}{|l|l|l|}
$\begin{array}{l}2 \\
(2)\end{array}$ & $(5)$ & 0 \\
$(3)$ & $(6)$ \\
\end{tabular} & & (9) (113) & (11) & & (2) \\
\hline & 2. 拱き & & (2) (9) (1) (1) & & (9) (13) & (14) & & \\
\hline 灰血 & 1. 吸教收重 & $\begin{array}{ll}\text { (8) } & \text { (1) } \\
\text { (9) } & \text { (1) } \\
\text { (11) } & \text { (1) } \\
\end{array}$ & $\begin{array}{|lll|}(2 & 5 & 1 \\
3 & (5) & 13 \\
(4) & (7)\end{array}$ & (7) & (1) (1) (1) (1) & & (9) (12) & $\begin{array}{ll}(4) & (7) \\
(5) & (14) \\
(6)\end{array}$ \\
\hline 巨み箱 & 1.こ外收集 & $\begin{array}{ll}\text { (8) } \\
\text { (1) } \\
\text { (1) } \\
\text { (1) }\end{array}$ & \begin{tabular}{|lll}
2 & 5 & 1 \\
3 & 6 & \\
3 & 6 & \\
4 & 0 & 0 \\
\end{tabular} & (4) & (9) & & $\begin{array}{l}\text { (8) (1) } \\
\text { (9) (12) } \\
\text { (11) (13) }\end{array}$ & $\begin{array}{|ll|}4 & 8 \\
5 & (1) \\
(6) & (14) \\
\end{array}$ \\
\hline $\begin{array}{l}\text { 金呞部分 } \\
\text { 分便所へだて }\end{array}$ & 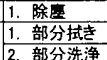 & & $\begin{array}{lllll}(3) & (4) & (5) & (6) & (7)\end{array}$ & & & & & \begin{tabular}{|c|}
5 \\
5
\end{tabular} \\
\hline
\end{tabular}

の「1. 除塵」といった清掃作業は、「1.1 自在篣・フロアダスター」 によるものと、「1.2 真空掃除機」によるものの 2 つの作業項目が設 定されており、前者は、建物(1)、(3)、(8)、および(9)〜(15)の 10 建物に おいて 1 回/日の周期で作業が実施され、建物(4)では 3 回／週の周 期で作業が実施されていることを示す注 1)。なお、表 3 についても同 様のみかたをされたい。

\section{3 管理データの収集状況}

各建物における管理データの収集範囲を表 4 に示す。なお、各建 物の一般管理費において、用度品費、雑費の支出は認められないこ とから、一般管理費を「委託管理費」「光熱水費」に分類して示す。
表3 床以外の清掃の作業項目および周期(日常清掃) (その2)

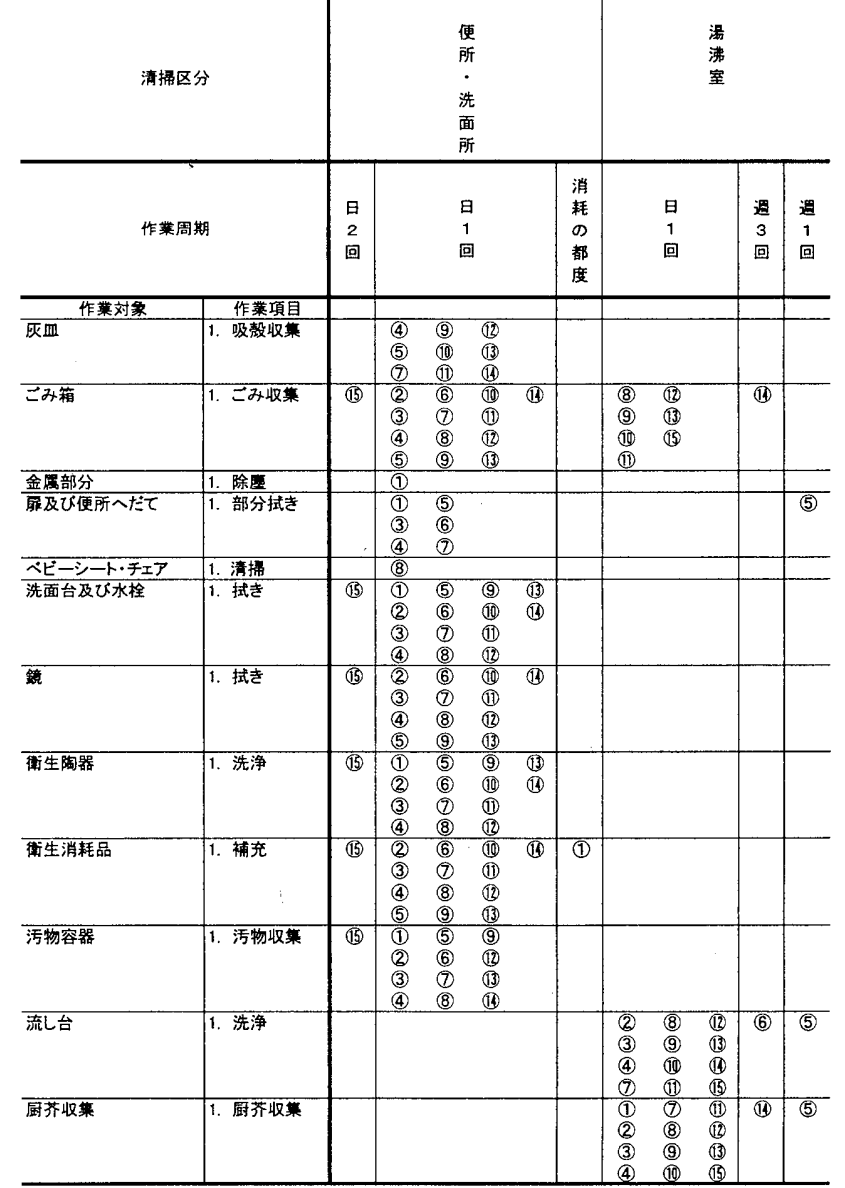


またこれらに対して次章にて進める経年変化に関する分析では、一 定期間以上の連続データを必要とすることから、対象建物には、2004 年度より最低 4 年間の連続データの提供を求めた。

表 4 をみるならば、建物(1)〜6ににおいて 4 年間の連続データを得 ることが可能であった。しかしながら、同表にも示したとおり、近 年その採用が増加している総合発注方式、すなわち電気設備、空調 設備などに対する保守・点検、さらには警備、清掃管理など、保安・ 清掃に含まれる各業務を一式で発注する方式が建物(2)、および(4)〜 (6)で導入されていることから、これらの建物においては、委託管理 費の総額の推移は把握できるが、それぞれの費目を分類することは 不可能であった。

\section{4. 管理費の分析}

ここでは、対象建物における管理費の全体像を示したうえで、清 掃管理費の位置付けを明らかにする。

\section{1 管理費の経年変化}

建物(1)〜6)の 6 建物における管理費を「委託管理費」「光熱水費」

表3 床以外の清掃の作業項目および周期(日常清掃) (その3)

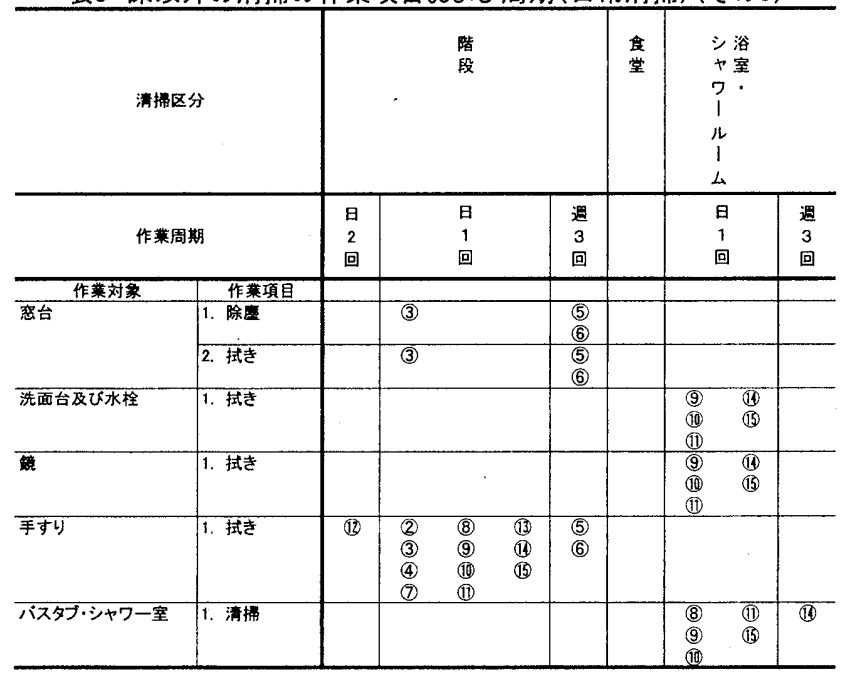

表3 床以外の清掃の作業項目および周期(日常清掃) (その4)

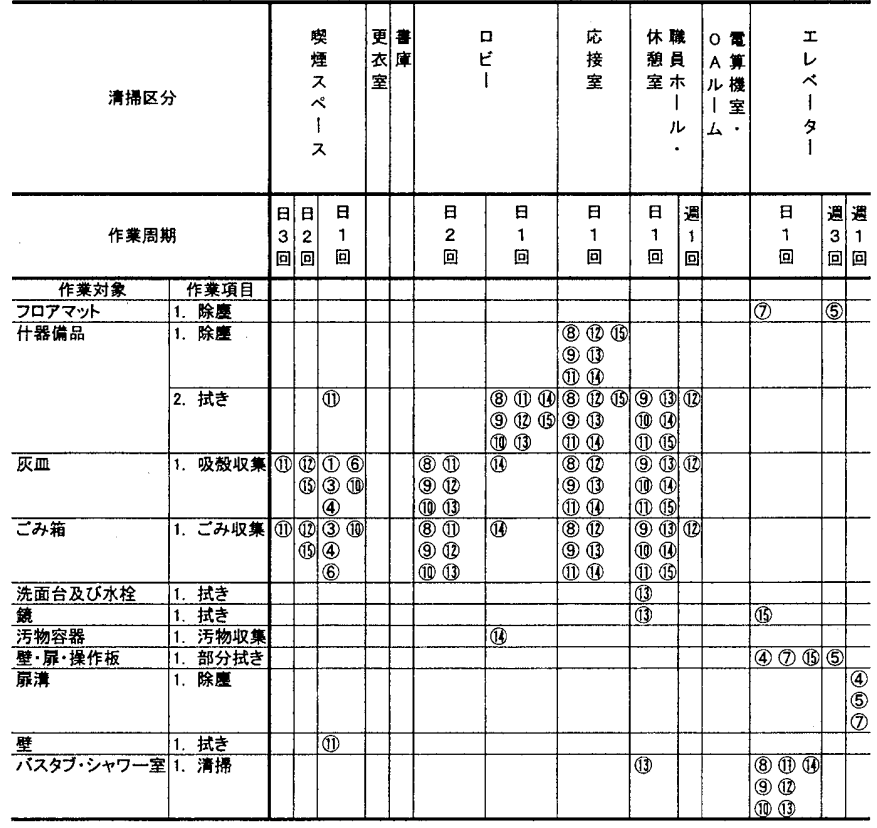

に分類し、最大で過去 5 年間の推移をそれぞれ図 2 に示す。

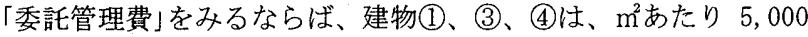


は、 $\mathrm{m}^{2} あ た り ~ 4,000$ 円前後でほぼ一定の推移を示しており、各建物 ともに経年による大きな变化は認められない。

6 建物のなかで建物(2)、(6)の支出は多いが、これら 2 建物はそれ ぞれ 2 棟で構成されており、それぞれの棟において空調や機械設備 の保守・点検が必要となっていることが起因している。

したがって、対象建物においては、mあたり 5,000 円〜6,000 円 の委託管理費を支出しているといえる。

「光熱水費「では、2003 年度にすべての建物で減少傾向が認められ る。これは冷夏に伴う夏期冷房でのエネルギー消費の減少が一因と して考えられる。しかしながら、昨今の省工ネ対策の効果からか、 2004 年度においても前年度と同様の支出で推移している。

そこで、最近 2 年間の支出を建物ごとにみるならば、建物(1)は、 mあたり 5, 000 円〜 6, 000 円、建物(2)は、 $\mathrm{m}^{2}$ あたり 4,000 円前後で 推移しており、これら 2 建物は他の 4 建物と比較して支出が大きい。 その理由として、建物(1)、(2)は、地方自治業務の中心的な役割を果 たしていることから、他の庁舎と比較して残業時間が長いことをと

表4 調査対象庁舎過去4年間における収集データ範囲

\begin{tabular}{|c|c|c|c|c|}
\hline 建物 & \multicolumn{2}{|c|}{ 委託管理费 } & \multirow{2}{*}{ 光熱水费 } & \multirow{2}{*}{$\begin{array}{c}\text { 清掃発注仕梯害 } \\
\text { (2004年度) }\end{array}$} \\
\hline No. & 保守·点検费 & 保安·清掃費 & & \\
\hline (1) & 0 & 0 & 0 & 0 \\
\hline (2) & \multicolumn{2}{|c|}{$\mathrm{O}^{\text {洼) }}$} & 0 & 0 \\
\hline (3) & $\mathrm{O}$ & 0 & 0 & 0 \\
\hline (4) & \multicolumn{2}{|c|}{$\mathrm{O}^{\text {洼) }}$} & 0 & 0 \\
\hline (5) & \multicolumn{2}{|c|}{$\mathrm{O}^{\text {洼) }}$} & 0 & 0 \\
\hline (6) & \multicolumn{2}{|c|}{$\mathrm{O}^{\text {洼) }}$} & 0 & $\mathrm{O}$ \\
\hline (7) & $x$ & $x$ & $x$ & 0 \\
\hline (8) & $x$ & $x$ & $x$ & $\mathrm{O}$ \\
\hline (9) & $x$ & $x$ & $x$ & 0 \\
\hline (10) & $x$ & $x$ & $x$ & 0 \\
\hline (11) & $x$ & $x$ & $x$ & 0 \\
\hline (11) & $x$ & $x$ & $x$ & 0 \\
\hline (13) & $x$ & $x$ & $x$ & 0 \\
\hline (14) & $x$ & $x$ & $x$ & 0 \\
\hline (15) & $x$ & $x$ & $x$ & 0 \\
\hline
\end{tabular}

注)建物(2)、(4)-6)総合請負により発注がなされているため、「保守点検费」、「保安清掃费」 の区分がなされていない。なお、表中の○印は、データ収集が可能であったものを示い、×印に ついては、データ収集が不可能であった建物を示す。



注) 凡例内の数字は、建物№を指す。

図2「委託管理費」·光熱水費」の推移 
アリングにより把握している。

以上の結果から、庁舎の地方行政における位置付けにより、その


り 3,000 円弱で推移していることから、対象建物における光熱水費 による支出は、mあたり 3,000 円程度であるといえる。

\section{2 清掃管理費の位置付け}

以降においては、前述した総合発注方式により、図 1 に示した「小 分類」の各費目が不明な建物については分析対象から除き、建物(1)、 (3)について「委託管理費」における「保守・点検費」「保安・清掃費」 の構成を示したうえで、管理費における清掃管理費の位置付けを明 らかにする。最大で過去 4 年間の推移をそれぞれ図 3 に示す。

建物(1)、(3)において、「保守・点検費」「保安・清掃費」の比率は ほぼ同等であり、経年による大きな变化も認められない。

つぎに、建物(1)、(3)における、「保安・清掃費」の内訳を図 4 にそ れぞれ示す。

建物(1)では、2004 年度において、警備費が前年比で約 3 倍となっ た影響から、清掃管理費の割合が大幅な減少を示している。しかし ながら、2003 年度以前においては、清掃管理費が「保安・清掃費」 のほぼ 8 割を占めている。また建物(3)では、清掃管理費は「保安 · 清掃費」のほぼ 5 割を占め、経年による大きな変化は認められない。

以上の分析から、対象建物における清掃管理費は、光熱水費の約

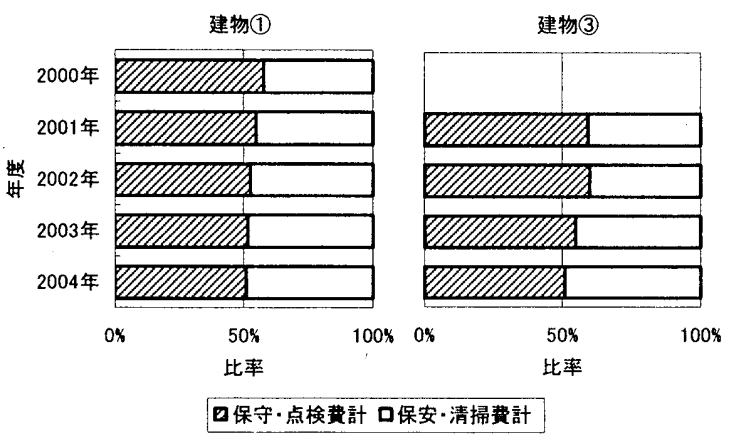

図3 委託管理費の構成
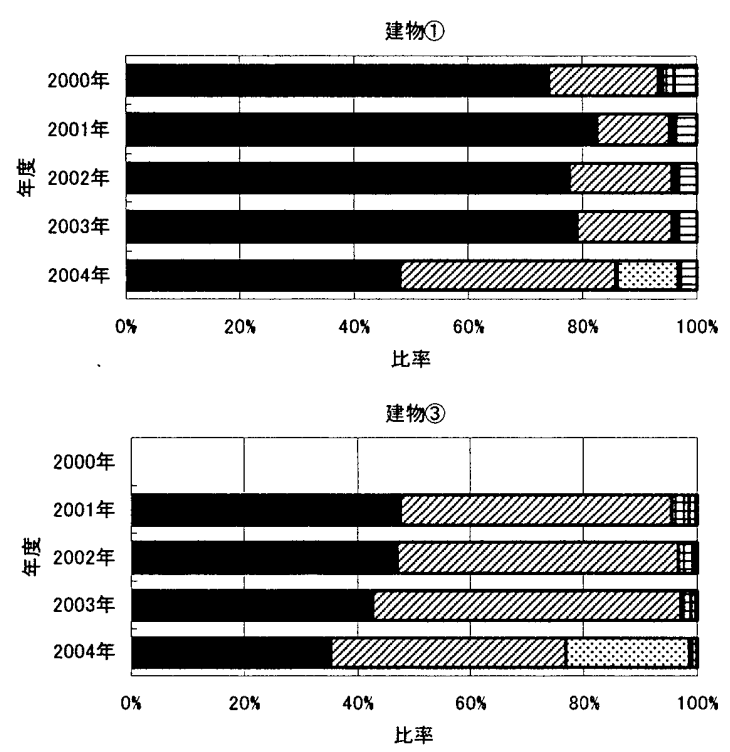



図4 保安·清掃費の構成
4 割〜6 割と同等の額であるといえる。

\section{5. 労務工数による清掃管理の分析}

前章では、対象建物における管理費の全体像を示したうえで、清 掃管理費の位置付けを明らかにした。ここでは、清掃管理費により 実際にどのような清掃管理がなされているのかについて、調査対象 である 15 建物の清掃発注仕様書に基づき、各清掃区分における労務 工数をそれぞれ算出し、清掃管理の実態を明らかにする。具体的に は、対象建物から提供された 2004 年度の清掃発注仕様書を分析対象 として、「建築保全業務共通仕様書」 ${ }^{11)}$ を用いて各仕様書における 作業内容の洗い出しをおこない、各作業内容を確定したうえで、「建 築保全業務積算基準 ${ }^{12}$ 、「ビルディングメンテナンスの積算 \& 見積」 ${ }^{13)}$ 、「月刊積算資料」 ${ }^{14)}$ 等を用いて各建物における労務工数を清掃 区分ごとに算出する。

\section{1 清掃発注面積の構成}

15 建物の年間における清掃発注面積の構成を、日常清掃、定期清 掃に区分してそれぞれ図 5 に示す。なお、このたび提供を受けた仕 様書において、年間の作業日数は 244 日、1 日の作業時間は 450 分 である。

図 5 をみるならば、すべての建物において、総発注面積に対する 定期清掃の発注面積はわずかであり、この傾向は建物(1)〜(7)で顕著 である。これは、建物(1)〜(7)では、日常清掃にお゙けるバフィング、 すなわち表層研磨による清掃を、ウェットクリーニングによる定期 清掃を低減させるといった理念のもとに発注者が推奨しているため と考えられる。しかしながら、建物(8)〜15にたいても定期清掃の発 注面積は、総発注面積の 1 割末満である。

\section{2 総労務工数の構成}

国土交通省による基準 ${ }^{12)}$ では、清掃作業に従事する技術者の就 業年数により、作業員 A、作業員 B、作業員 C といった各レベルに対 してそれぞれ異なった歩撕りが設定されている。したがって、同一 の作業を同一の室で実施した場合でも、作業に要する時間が各レベ ルにより異なる。さらに基準では、庁舎の規模、すなわち清掃発注



図5 年間における清掃発注面積の構成 
面積の大小により、作業員のレベル、作業人数が設定されている。

例えば、玄関ホールにおいて、床以外の日常清掃では「フロアー マット徐塵」「扉ガラス部分拭き」「什器備品徐應」「吸款収集」「ご み収集及び金属部分徐塵」の 5 項目に対する歩掛りが文献 ${ }^{12)} に$ 設 定されている。また、清掃発注面積が $1,000 \mathrm{~m}^{2}$ 以下の庁舎において、 これら 5 項目の清掃は作業員 Bが1 人で従事することを前提として、 その歩掛りが設定されている注 2)。しかし、清掃発注面積が 5,000 $\mathrm{m}^{2}$ を超える規模の庁舎になると、前述した玄関ホールの各作業は、 作業員 $A 、$ 作業員 B、作業員 Cがそれぞれ 1 人ずつ計 3 名により従事 することを前提として、それぞれの作業員に対する歩措りが設定さ れている注3)

本研究の調查対象は、すべて清掃発注面積が $5,000 \mathrm{~m}^{2}$ を超える規 模であることから、ここでは 1 建物において、各レベルの作業員が それぞれ 1 人ずつ作業に従事した場合の労務工数を、日常清掃、定 期清掃ごとにそれぞれ算出している。各建物の算出結果を図 6 にそ れぞれ示す。

図 6 をみるならば、前項で示した図 5 では、定期清掃の占める割 合が非常に小さかったのに対し、労務工数の割合においては定期清 掃に要する労務工数が日常清掃を上回っている建物も認められ、そ の傾向は建物(8)〜15)で顕著である。これは、事務室、会議室におけ る委託清掃は定期清掃のみによるといった、一部の清掃区分におい て日常・定期の発注面積に違いが認められること、また廊下・EV ホ 一ルなどのように、日常・定期の両発注において、発注面積は同様 であるが、文献 ${ }^{12)} に$ において設定されている歩掛りが日常・定期の 両者間において開きが認められること、以上の 2 つが要因として考 えられる。このうち、日常・定期において歩措りに開きがある理由 は、通常、日常清掃はドライクリーニングにより実施され、定期清 掃はウェットクリーニングにより実施されていることにある。ちな みに廊下・EV ホールにおける代表的な日常清掃 [除塵及び部分水拭 き〕の歩掛りは 0.003、代表的な定期清掃〔表面洗浄〕の歩掛りは 0.069 に設定されている ${ }^{12}$ 。

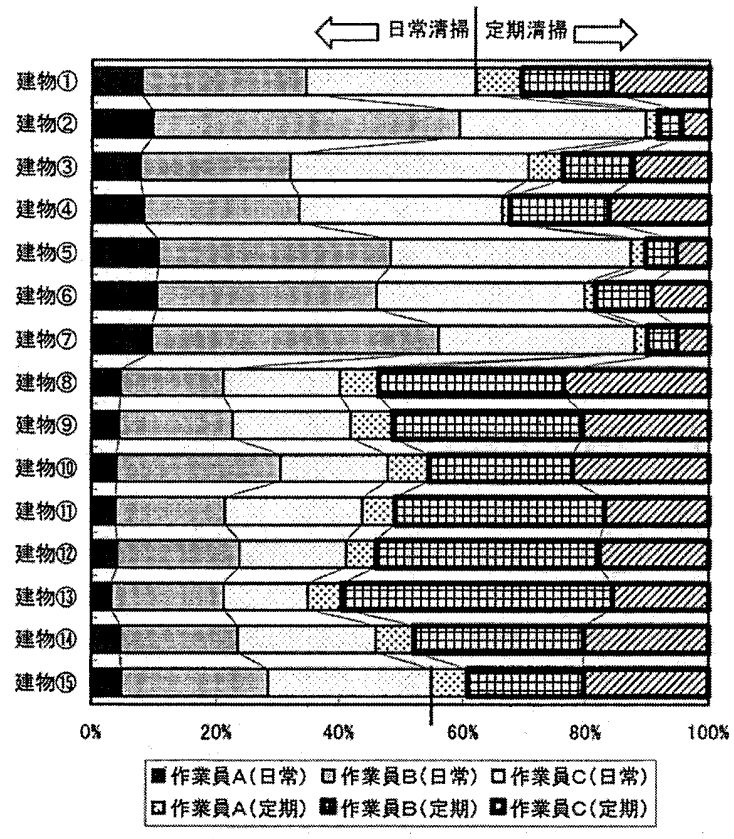

図6 年間における総労務工数の構成
これにより、日常清掃と比較して、定期清掃は多工数の作業が多 く存在し、労務工数が直接関係する清掃管理費の大小に強い影響を 及ほしていることがわかる。

\section{3 各清掃区分における労務工数}

ここでは表 2、および表 3 に示した清掃の作業項目および周期の なかで、ほぼ標準的な仕様注 4)であると考えられる建物(8)を例とし て、総労務工数を清掃区分ごとに集計した。結果を日常清掃、定期 清掃ごとにそれぞれ図 7 に示す。なお、対象建物においては、建物 ごとに室名称が異なるため、庁舎内の各室を文献 ${ }^{11)}$ に記載されて いる清掃区分に整理した注5)。

図 7 の日常清掃をみるならば、「廊下・EV ホール」「便所・洗面所」 が突出しており、「玄関ホール」がこれに続いている。また、これら の労務工数の全体に占める割合性、順に $23.6 \% 、 22.5 \% 、 16.3 \%$ で あり、これら 3 区分で日常清掃における総労務工数の約 6 割を占め ることがわかる。また、定期清掃では、「照明器具」「事務室」がそ れぞれ定期清掃における総労務工数の $29.2 \% 、 27.0 \%$ 占めている。

したがって、清掃管理費削減を検討する際には、これら 4 区分 1 作業の労務工数管理を重点的に行う必要があると考える。また、図

\section{日常清掃}

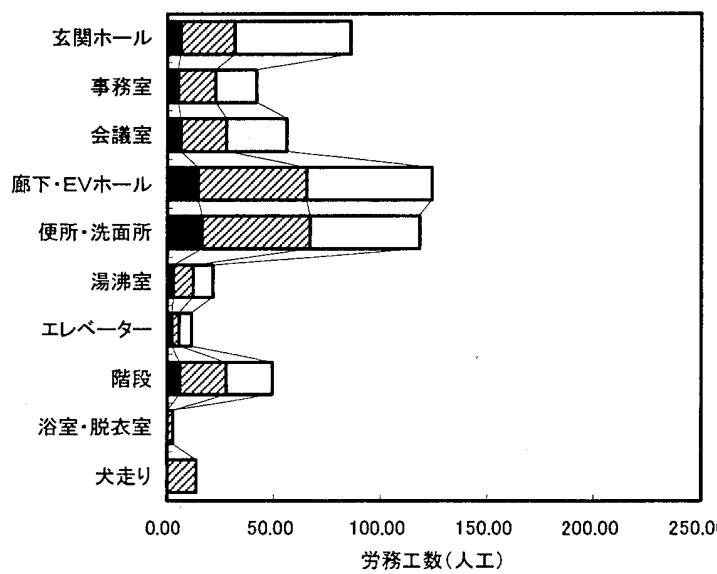

作業員A(日常) 日作業員B(日常) 口作業員C(日常)

定期清掃

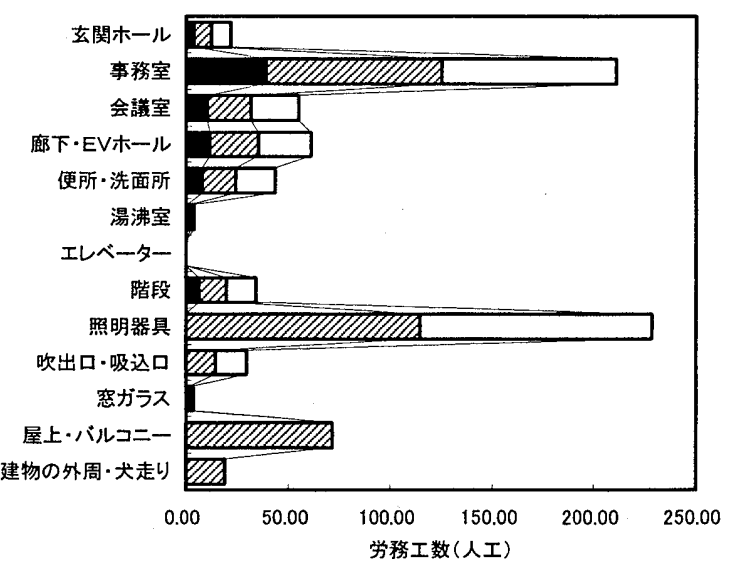

口作業員A(定期) 口作業貣B(定期) 口作業貝C(定期)

図7 各清掃区分における労務工数 
示は省略したが、この分析は他の 14 建物に対しても同様に実施して おり、他の建物においてもほぼ同様の結果を得ている。

\section{4 各清掃区分における清掃所要時間}

ここでは、日常清掃における各清掃区分での1日あたり清掃面積 と清掃所要時間の関連について検討寸るため、1 日あたり清掃面積 を横軸、各清掃区分における 1 日あたり清掃所要時間を繸軸にとり 各清掃区分を布置した。ここでも建物(8)の結果を図 8 に示す。なお、 ここでの清掃所要時間は、作業員 A、作業員 B、作業員 Cがそれぞれ 1 人ずつ計 3 名により従事することを前提とした合計值である。

図8をみるならば、「廊下・EVホール」は、1 日あたり清掃発注面 積が最も大きく、かつ清掃所要時閒が最も長い区分であるといえる。 また、「便所・洗面所」の発注面積は「廊下・EV ホール」と比較し て小さいが、清掃所要時間は「廊下・EV ホール」とほぼ同程度であ ることから、比較的作業負荷の高い清掃区分となっていることがわ かる。

\section{6. 結語}

本研究では、地方政令市に建つ複数の庁舎より収集した管理費の 分析より管理費の全体像を示したうえで、委託管理費を焦点にさら なる分析を進め、清掃管理費の位置付けを明らかにした。そこでは、 対象建物における清掃管理費による支出は、光熱水費の約 4 割〜 6 割と同等の額であるということを明らかにした。

つぎに、清掃管理費により実際にどのような清掃管理がなされて いるのかについて、調查対象である 15 建物の清掃発注仕様書に基づ いた労務工数による分析から清掃管理の実態を明らかにした。まず、 発注面積および総労務工数の構成に関する分析から、発注面積の構 成に扔いては、各対象建物ともに定期清掃の占める割合は日常清掃 と比較して非常に小さいが、労務工数の割合では定期清掃に要する 労務工数が日常清掃を上回っている建物も認められ、定期清掃は日 常清掃と比較して、多工数の作業が多く存在し、労務工数が直接関 係する清掃管理費の大小に強い影響を及ぼしていることを明らかに した。つぎに、各清掃区分における労務工数に関する分析から、日 常清掃の「廊下・EV ホール」「便所・洗面所」「玄関ホール」、定期 清掃の「照明器具」「事務室」は、それぞれ高い労務工数を要してい

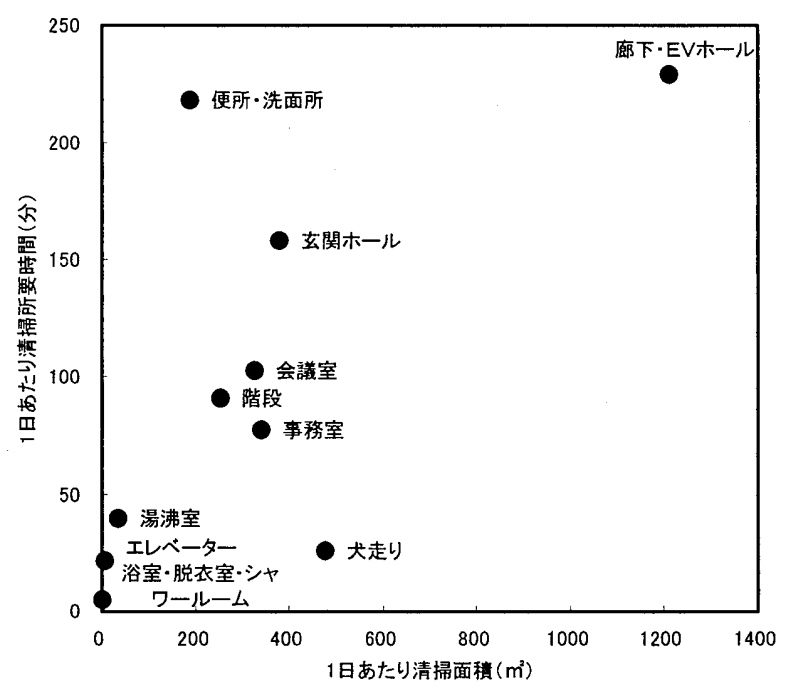

図8 各清掃区分における1日あたり清掃所要時間と清掃面積の関連
ることから、清掃管理費削減を検討する際には、これら 4 区分 1 作 業の労務工数管理を重点的に行う必要があることを明らかにした。 さらに、日常清掃における各清掃区分での 1 日あたり清掃面積と清 掃所要時間の関連について検討した結果、「廊下・EVホール」は、1 日あたり清掃発注面積が最も大きく、かつ清掃所要時間が最も長い 区分であるといえ、「便所・洗面所」は作業負荷の高い清掃区分であ ることを明らかにした。

本研究の成果を踏まえ、今後の展開について述べる。

本研究は、費用資料による労務工数の算出結果に基づき論考を進 めている。また本研究において、労務工数の算出に用いた文献 ${ }^{11-14)}$ は、発注者・受注業者が、予算・実施価格を算出する際に資料とし て用いられているものである。しかしながら、これらの費用資料は 多岐にわたることから、同一作業における労務工数の推定方法が共 通であるとはいいがたい。

したがって今後の展開としては、各清掃区分におうける清掃作業内 容の実態と、歩拱りの整合について検証するために、歩掛り設定に 必要となる清掃作業そのものに対する調查が必要であると考える。

\section{謝辞}

本研究を進めるにあたり、国土交通省大臣官房官庁営繥部計画課保全指導 室、松村高俊氏、三ツ木浩剛氏の両氏に助言を頂いた。ここに記し、哚く感 謝申し上げます。

注

注 1)各調查対象建物における具体的な清掃内容は「参考文献 11」を参照された い。

注 2)「参考文献 12 」において、清掃発注面積が 1,000 $\mathrm{m}^{2}$ 以下の建物における玄関 ホールの日常清掃は、作業員 B のみにより実施されることが規定されている。 例えば、玄関ホールにおける日常の床以外に対する清掃（「フロアーマット 徐塵」「扉ガラス部分拭き」「什器備品徐塺」「吸款収集」「ごみ収集及 び金属部分徐塺」）には、床 $100 \mathrm{~m}^{2} 1$ 回あたり 0.048 の歩撕りが設定されて いる。すなわち䒺関ホール林 $100 \mathrm{~m}^{2}$ において、上述した 5 つの作業に要する 清掃作業時間は、 450 分[一日の作業時間 $] \times 0.048$ [歩掛り]により算出され、 21.6 分/床 $100 \mathrm{~m}^{2}$ となる。

注 3)「参考文献 12」において、清掃発注面積が $5,000 \mathrm{~m}^{2}$ を超える建物における玄 関ホールの日常清掃は、作業員 A、作業員 B、作業員 C の 3 名により実施さ れることが規定されている。例えば、去関ホールにおける日常の床以外に対 する清掃（「フロアーマット徐塵」「屝ガラス部分拭き」「什器備品徐塵」 「吸凯収集」「ごみ収集及び金属部分徐塵」）には、床 $100 \mathrm{~m}^{2} 1$ 回あたりそ れぞれ $0.006 、 0.021 、 0.021$ の歩撕が設定されている。すなわち玄関ホール

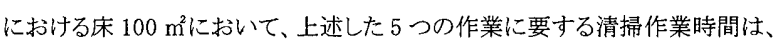
作業員 A に打いて 450 分[一日の作業時間] $\times 0.006$ [歩掛り]、同樣に作業 員 B·C では、それぞれ $450 \times 0.021$ により算出され、それぞれの清掃作業時 間は 2.7 分/床 $100 \mathrm{~m}^{2} 、 9.45$ 分/床 $100 \mathrm{~m}^{2} 、 9.45$ 分/床 $100 \mathrm{~m}^{2} と な る 。$

注4)ここでの標淮的な仕様とは、表 2、および表 3 の各清掃区分において、作業周 期ごとに欄を分けて建物を表しているが、ほぼ常に多くの建物が属する欄に、 位置する建物のことを指している。

注 5) 建物によって室名称に差異が認められたため、以下に示すとおり、文献 12)に 示されている清掃区分に各室を分類した。スロープ、ギャラリー、玄関EVホー ル、ふれあいコーナー、待合ホール、県民ホール、ロビーといった各室は「玄 
関ホール」に分類し、以下同様に、畫庫、休愨室、職員ホール、更衣室、ロッ カールーム、電算機室、OAルームは「事務室」に、記者会見室、応接室、知 事室、副知事室、会議室内倉庫・通路は「会議室」に、避難階段、屋外階段 は「階段」に、庭園、中庭は「玄関周り」に、ランプ・構内通路、渡り廊下、構内 满は「構内通路」に、バルコニー、屋根は「屋上広場」に分類した。

\section{参考文献}

1) 杉田 洋, 村川三郎, 藤上輝之, 西名大作:庁舎におけるリニューアルの実態と その実施時期判断手法の適用性の検証, 日本建築学会計画系論文集, No.553, pp.275-282, 2002.3

2)関内健治, 石原 勉, 岸 正, 田野昌治, 古橋秀夫:病院清掃における凟機材の カラーリング, 環境の管理, 日本環境管理学会誌, No.18, pp.73-77, 1996.11

3)水野隆晴:病院清掃とクリーンクルーの自己管理 一院内感染対策室からの報 告一, 環境の管理, 日本環境管理学会誌, No.16, pp.75-78, 1995.10

4) 上原弘三, 村松 學, 庭由 茂:オフィスビルにおけるダニアレルゲン污染調査と アレルダンコントロールの試み, 環境の管理, 日本環境管理学会誌, No.38, pp.33-38, 2002.3

5) 大塚健次, 村松年郎, 生田実香, 村松 學, 雨谷敬史, 長田英二:喫煙の室内 污染に及ぼす影響, 環境の管理, 日本環境管理学会誌, No.48, pp.47-57,
2003.12

6)清水 晋, 大迴和彦:空調ダクト污染の簡易測定法による実測調査, 環境の管理, 日本環境管理学会誌, No.47, pp.1-2,2003.10

7)吉由正広, 清水 晋:ダクト污染および清掃効果の実測調查, 環境の管理, 日本 環境管理学会誌, No.47, pp.7-8, 2003.10

8)杉田 洋, 佐藤隆良, 村川三郎, 平賀 慎, 大石洋之:某庁舍における清掃発注 仕様の品質評価に関する研究，日本建築学会計画系論文集，No.600, pp.153-159, 2006.2

9)杉田 洋, 佐藤隆良, 村川三郎, 平賀 慎:庁舎における FM 管理手法に基づい た清掃発注仕様の品質評価に関する研究, 日本建築学会計画系論文集, No.600, pp.161-169, 2006.2

10)(社)建築·設備維持保全推進協会編:ビルディング LC ビジネス大百科,オーム 社, 1992

11) 国土交通省大臣官房官庁営繥部編,建築保全業務共通仕様書,(財)建築保全 センター,2003

12) 国土交通省大臣官房官庁営縡部編,建築保全業務積算基準,(財)建築保全セ ンター,2003

13)ビルディングメンデナンスの積算 \&見積,(株)日本ビル新閶社,2004

14) 月刊積算資料, (財)経済調查会,2004 